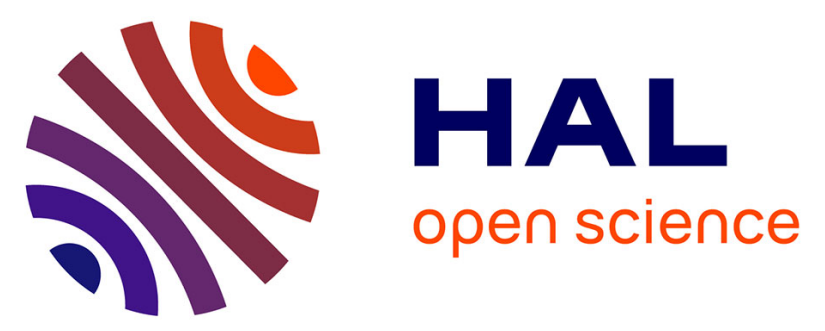

\title{
New insights on the Vélodrome syncline in the western sub-alpine foreland basin of Haute Provence : 3-D geometrical modelling approach
}

\author{
Agathe Faure, Laurent Jolivet, Charles Gumiaux, Cécile Allanic, Gautier \\ Laurent, Nicolas Loget, Jean-Paul Callot, Myette Guiomar
}

\section{To cite this version:}

Agathe Faure, Laurent Jolivet, Charles Gumiaux, Cécile Allanic, Gautier Laurent, et al.. New insights on the Vélodrome syncline in the western sub-alpine foreland basin of Haute Provence: 3-D geometrical modelling approach. vEGU21: Gather Online, Apr 2021, Online, France. 10.5194/egusphere-egu2112342. hal-03554521

\author{
HAL Id: hal-03554521 \\ https://hal.science/hal-03554521
}

Submitted on 3 Feb 2022

HAL is a multi-disciplinary open access archive for the deposit and dissemination of scientific research documents, whether they are published or not. The documents may come from teaching and research institutions in France or abroad, or from public or private research centers.
L'archive ouverte pluridisciplinaire HAL, est destinée au dépôt et à la diffusion de documents scientifiques de niveau recherche, publiés ou non, émanant des établissements d'enseignement et de recherche français ou étrangers, des laboratoires publics ou privés. 
EGU21-12342, updated on 03 Feb 2022

https://doi.org/10.5194/egusphere-egu21-12342

EGU General Assembly 2021

(c) Author(s) 2022. This work is distributed under

the Creative Commons Attribution 4.0 License.

\title{
New insights on the Vélodrome syncline in the western sub-alpine foreland basin of Haute Provence : 3-D geometrical modelling approach
}

\author{
Agathe Faure ${ }^{1}$, Laurent Jolivet ${ }^{1}$, Charles Gumiaux ${ }^{2}$, Cécile Allanic ${ }^{3}$, Gautier Laurent ${ }^{2}$, Nicolas \\ Loget ${ }^{1}$, Jean-Paul Callot ${ }^{4}$, and Myette Guiomar ${ }^{5}$ \\ ${ }^{1}$ Sorbonne Université, CNRS-INSU, Institut des Sciences de la Terre de Paris (ISTeP), UMR 7193 - France \\ ${ }^{2}$ Université d'Orléans, CNRS-INSU, Institut des Sciences de la Terre d'Orléans (ISTO), UMR 7327 - France \\ ${ }^{3}$ Bureau de Recherches Géologiques et Minières (BRGM) - France \\ ${ }^{4}$ E2S UPPA CNRS/TOTAL/Univ Pau \& Pays Adour, Laboratoire Des Fluides Complexes Et Leurs Reservoirs-IPRA, UMR5150 - \\ France \\ ${ }^{5}$ Réserve Naturelle Nationale Géologique de Haute Provence (RNNGHP), Conseil départemental des Alpes de Haute- \\ Provence - France
}

In the front of the Digne thrust, the deformed foreland basin, the well exposed tectonic window of Barles, is still not well understood. This region has undergone a complex tectonic history involving synsedimentary deformation, potential migration of alpine front, late exhumation related to surface processes and potential salt tectonics. Although the stratigraphy and the structural geology of the area is well known, the respective contributions of regional tectonics, salt tectonic and surface processes remain uncertain. The region displays still enigmatic objects emplaced at each step, from the rifting phase to the late exhumation, such as the overturned Liassic Barre de Chine or the overturned Miocene syncline of the Vélodrome. This study aims at understanding the evolution of the foreland Valensole basin from the deposition of first sediments 30Ma ago to late exhumation and relief formation. We focused our work on the emblematic Vélodrome syncline which is also the only place where a continuous sequence of the basin deposits is exposed. The molassic and conglomeratic layers of the Vélodrome form an overturned syncline with a curved axis of which direction changes from EW in the north to NS in the most south-eastern part. The Vélodrome has been studied for more than a century but its history is still debated. If the Vélodrome is often interpreted as a growth fold which explain the observation of progressive unconformities, microstructural analyses (Fournier et al., 2008) suggest that folding postdates sedimentation. Moreover, recent studies (Graham et al., 2012) propose that this spectacular fold formed as a result of salt tectonic. The obliquity of the regional shortening direction regarding the axis direction, the 3-D pattern of the overturned Miocene series and the origin of the progressive unconformities are issues still not resolved. Such a complex tectonic structure as the Vélodrome fold requires a thorough understanding of the 3-D geometries and their evolution through time. Based on field observations and 3-D geometrical modelling (GeoModeller - CBRGM), we propose a preliminary model of the Vélodrome that brings new insights on this part of the Valensole basin. The implicit approach that offer the GeoModeller and the field structural data-based approach 
(here more than 2000 structural data) bring an objective and new vision of the geometries in 3-D of the Vélodrome basin and provide arguments to determine the contribution of each geological processes in the tectonostratigraphic evolution of the north margin of the Valensole basin and subsequent shortening at the western subalpine front. 